Article

\title{
Fact-Checking Interventions as Counteroffensives to Disinformation Growth: Standards, Values, and Practices in Latin America and Spain
}

\author{
Victoria Moreno-Gil ${ }^{1}$, Xavier Ramon ${ }^{2, *}$ and Ruth Rodríguez-Martínez ${ }^{2}$ \\ ${ }^{1}$ Nebrija University, 28015 Madrid, Spain; E-Mail: vmorenog@nebrija.es \\ 2 Department of Communication, Pompeu Fabra University, 08018 Barcelona, Spain; E-Mails: xavier.ramon@upf.edu (X.R.), \\ ruth.rodriguez@upf.edu (R.R.-M.)
}

* Corresponding author

Submitted: 6 July 2020 | Accepted: 27 August 2020 | Published: 3 March 2021

\begin{abstract}
As democracy-building tools, fact-checking platforms serve as critical interventions in the fight against disinformation and polarization in the public sphere. The Duke Reporters' Lab notes that there are 290 active fact-checking sites in 83 countries, including a wide range of initiatives in Latin America and Spain. These regions share major challenges such as limited journalistic autonomy, difficulties of accessing public data, politicization of the media, and the growing impact of disinformation. This research expands upon the findings presented in previous literature to gain further insight into the standards, values, and underlying practices embedded in Spanish and Latin American projects while identifying the specific challenges that these organizations face. In-depth interviews were conducted with decision-makers of the following independent platforms: Chequeado (Argentina), UYCheck (Uruguay), Maldita.es and Newtral (Spain), Fact Checking (Chile), Agência Lupa (Brazil), Ecuador Chequea (Ecuador), and ColombiaCheck (Colombia). This qualitative approach offers nuanced data on the volume and frequency of checks, procedures, dissemination tactics, and the perceived role of the public. Despite relying on small teams, the examined outlets' capacity to verify facts is noteworthy. Inspired by best practices in the US and Europe and the model established by Chequeado, all the sites considered employ robust methodologies while leveraging the power of digital tools and audience participation. Interviewees identified three core challenges in fact-checking practice: difficulties in accessing public data, limited resources, and the need to reach wider audiences. Starting from these results, the article discusses the ways in which fact-checking operations could be strengthened.
\end{abstract}

\section{Keywords}

disinformation; fact-checking; journalism; Latin America; Spain

\section{Issue}

This article is part of the issue "Disinformation and Democracy: Media Strategies and Audience Attitudes" edited by Pere Masip (University Ramon Llull, Spain), Bella Palomo (University of Málaga, Spain) and Guillermo López (University of Valencia, Spain).

(C) 2021 by the authors; licensee Cogitatio (Lisbon, Portugal). This article is licensed under a Creative Commons Attribution 4.0 International License (CC BY).

\section{Introduction}

The normative theories of media highlight that socially responsible journalism should provide truthful, complete, and accurate information to help citizens understand public affairs and, having been informed, to participate in the community (Christians, Glasser, McQuail, Nordenstreng, \& White, 2009). Nevertheless, journalism's ability to comply with this normative goal is increas- ingly threatened by a combination of profound challenges and provocations. Digital transformations have come at a cost for legacy media, which "have suffered from the collapse of the traditional advertising-funding model combined with dwindling circulation numbers" (Ramon \& Tulloch, 2019, p. 2). In addition, the expansion of 'ASAP journalism' (Usher, 2018) news culture has diminished opportunities for thorough investigations, source-checking, and verification, thus limiting 
the proper operation of journalism's watchdog function (Zelizer, 2018). Furthermore, the growth of practices linked to commodification, such as click-baiting, have challenged journalism's traditional norms and values. The fixation on metrics has also led news organizations and other actors to stimulate "polarized over moderate views" (McCluskey \& Kim, 2012, p. 566). In a context characterized by political instability and the rise of populism, increasing partisanship is arguably problematic, since polarized media systems can also lead to polarized societies (Allcott \& Gentzkow, 2017).

The disturbing spread of disinformation unmistakably poses the latest "existential challenge to journalists dealing with an audience losing its faith in what journalism does" (Richardson, 2017, p. 1). The rise of disinformation can be attributed, among other factors, to the politicization of the media, citizens' distrust towards institutions, and the psychological biases and social rewards that drive individuals to share fake news (García-Marín, 2020). Given that citizens are increasingly employing mobile devices and social media to access content (Newman, 2020), the spread of disinformation through digital platforms "can eventually lead to false beliefs or factual misperceptions, posing vexing problems on democratic decision-making" (Hameleers \& van der Meer, 2020, p. 230).

Graves and Anderson (2020) consider fact-checking as a strand of contemporary journalism while Amazeen (2020, p. 98) refers to fact-checking platforms as interventions that appear "when a threat is perceived." Precisely, as democracy-building tools, fact-checking operations serve as critical interventions in the fight against the expansion of false and/or misleading news. As part of a global movement, these entities scrutinize the claims of public representatives and alert citizens to online disinformation. In the process, they attempt to "revitalize the 'truth seeking' tradition in journalism" (Graves, 2016, p. 6).

Internal fact-checking originated in the US during the first decades of the twentieth century. However, the rise and consolidation of modern fact-checking platforms is much more recent (Amazeen, 2020). The creation in 2003 of FactCheck.org at the Annenberg Public Policy Center at the University of Pennsylvania paved the way for the appearance in 2007 of The Washington Post's Fact Checker and PolitiFact.com, a non-profit project developed by the Tampa Bay Times (then, the St. Petersburg Times) which is now operated by the Poynter Institute for Media Studies. Fact-checking initiatives rapidly made inroads into other countries, being introduced by organizations such as Channel 4 (2005), Libération (2008), and Le Monde (2009). The growth of disinformation related to political elections and events such as the Brexit referendum facilitated the expansion of fact-checking operations, which have gained visibility and legitimacy over the years (Lowrey, 2017).

Graves (2018) emphasizes that fact-checking is a global movement. In 2015, the Poynter Institute estab- lished the International Fact-Checking Network (IFCN) to bring together fact-checkers from around the world. Besides organizing an annual Global Fact-Checking Summit, the IFCN promoted a code of principles signalling its signatories' commitment to: (1) nonpartisanship and fairness; (2) standards and transparency of sources; (3) transparency of funding and organization; (4) standards and transparency of methodology; and (5) an open and honest corrections policy. The Reporters' Lab at the Sanford School of Public Policy at Duke University notes that there are currently 290 active fact-checking sites in 83 countries (Stencel $\&$ Luther, 2020). These organizations are remarkably diverse but can be classified under the two models described by Graves and Cherubini (2016): the 'newsroom model' and the 'NGO' model. The first refers to factchecking units operating within established news organizations; the second to initiatives that do not belong to newsrooms. Over the last few years, digital technologies have lowered production barriers (Singer, 2018), enabling new figures to enter the fact-checking scene. This includes non-profit independent projects, platforms linked to NGOs or developed by or in collaboration with universities, such as the RMIT ABC Fact Check in Australia (Farrer, 2017).

In spite of this diversity, the movement is characterized by its "shared discourse and overlapping practices" (Graves, 2018, p. 614). An essential trait of fact-checking is the embodiment of scientific objectivity to overcome the 'he-said/she-said' reporting style that has pervaded contemporary journalism practice. The systematic factchecking process involves the following steps: (1) selecting statements of public interest; (2) identifying evidence and context to scrutinize the accuracy of those claims; and (3) writing and publicizing assessments (UNESCO, 2018). Singer's (2020) interviews with fact-checkers on four continents revealed that fact-checkers consider accuracy, impartiality, accountability, objectivity, independence, transparency, and completeness as essential cornerstones of their work. Fact-checkers also perceive that their task is "not only a complement but also a corrective for mainstream media," especially in territories where media are "relatively weak," "servile" and "strong on spreading fake news and spin" (Singer, 2020, p. 9).

Fact-checking projects are run by small teams of journalists who leverage technology to develop and disseminate their work (Graves, 2018). Notably, professionals embrace verification tools such as TinEye, Google Reverse Search, and FotoForensics, which assist them in the "process of authenticating online content items such as text, images, and videos" (Brandtzaeg, Følstad, \& Chaparro Domínguez, 2018, p. 1110). Online options have also allowed fact-checking projects to disseminate verifications through textual and multimedia elements (Vázquez-Herrero, Vizoso, \& López-García, 2019). Digital platforms have also allowed these projects to cultivate close relationships with their audiences (Singer, 2018). According to fact-checkers, serving audiences not only 
implies reaching them but also educating them through media literacy (Singer, 2020).

Previous studies have indicated the potential of factchecking to counter disinformation and political polarization (Hameleers \& van der Meer, 2020). Researchers have also highlighted the challenges that hinder the development of fact-checking, such as limited visibility, resource and time constraints, and the incipient development of machine learning (Humprecht, 2020; Lowrey, 2017; Molina, Sundar, Le, \& Lee, 2019). Research on pioneering platforms in the US context paved the way for subsequent analyses focused on other territories such as the UK, Germany, Austria, Ukraine, and sub-Saharan Africa (Cheruiyot \& Ferrer-Conill, 2018; Haigh, Haigh, \& Kozak, 2018; Humprecht, 2019; Singer, 2020).

\section{Fact-Checking in the Latin American and Spanish contexts}

Following the US model, Latin American and Spanish factchecking platforms started operating in 2010 with the launch of Chequeado (Argentina), which set an example for many subsequent outlets regarding methodology and workflow. Historically, Spain and Latin America have had remarkable similarities, such as commentaryoriented journalism, low levels of newspaper circulation, instrumentalization, and limited journalistic autonomy (Hallin \& Papathanassopoulos, 2002). Traditionally, the Spanish landscape has been characterized by a high level of polarization in the public sphere and the political classes' strong influence over journalism (Baumgartner \& Bonafont, 2015; Masip, Ruiz, \& Suau, 2018). Along with other problems such as job precariousness, Spanish journalists remain deeply concerned by the politicization of the media, its dependence on institutional sources, and pressure from government (Luengo, Maciá-Barber, \& Requejo-Alemán, 2017; Mauri-Rios, López-Meri, \& Perales-García, 2020).

In the same vein, Latin America is a region that "has traditionally faced serious obstacles to achieving genuine media democracy" (Palau-Sampio, 2018, p. 352). First, journalists' access to public data has been widely restricted. According to Saldaña and Mourão (2018, p. 319), "despite the approval of laws granting access to information in most countries, practice is still limited by uneven implementation and bureaucratic delay tactics." Second, journalistic autonomy has been threatened by the "close ties between government and eliteowned media organizations" (Saldaña \& Mourão, 2018, p. 311). According to Freedom House and Reporters Without Borders, high media concentration and close links between the media's ownership and the political class in the region results in self-censorship and the slackening of media pluralism. Intimidation, harassment, and violence against journalists who cover sensitive topics are not limited to countries such as Colombia since it also occurs in other territories such as Argentina, Uruguay, and Chile. In Ecuador, media freedom has improved since
Lenin Moreno became president in 2017, but local officials and authorities "are still responsible for implementing assaults on the press through legislative, judicial, and administrative means" (Freedom House, 2020). In Brazil, attacks have intensified on journalists and outlets critical of Jair Bolsonaro, who was elected in 2018 "after a campaign marked by hate speech, disinformation, violence against journalists and contempt for human rights" (Reporters Without Borders, 2020).

Disinformation is a growing concern both in Latin America and Spain. As the Reuters Institute Digital News Report highlights, disinformation is a major threat in those countries "where social media use is high and traditional institutions are often weaker" (Newman, 2020, p. 17). According to the Reuters Institute survey, politicians are seen as most responsible for spreading disinformation, followed by political activists and journalists. Political strife and the high levels of polarization in countries such as Argentina, Brazil, Chile, or Spain have facilitated the circulation of false and misleading news, mostly throughout social media platforms and messaging apps.

In the face of such shared challenges, independent fact-checking platforms have flourished across Latin America and Spain (Stencel \& Luther, 2020). Several exploratory studies have offered an overview of the organizational structures and methods deployed by Spanish-language fact-checking sites (Bernal-Triviño \& Clares-Gavilán, 2019; López-Pan \& Rodríguez-Rodríguez, 2020; Palomo \& Sedano, 2018; Rodríguez-Pérez, 2020; Vizoso \& Vázquez-Herrero, 2019). Other contributions have focused on the task carried out by independent fact-checkers during political campaigns (Chaves \& Braga, 2019; Magallón-Rosa, 2019; Vizoso \& López-García, 2019). Combining quantitative and qualitative approaches, Palau-Sampio (2018) examined nine fact-checking projects in six Latin American countries to analyse their workflows as well as the topics and actors that are on their agendas. The study revealed that those sites prioritize political and social issues, especially those that intersect with education, health, and the economy. Recently, Ufarte-Ruiz, Anzera, and Murcia-Verdú (2020) compared fact-checking outlets in Spain (Maldita.es and Newtral) and Italy (Pagella Politica). The study revealed that these fact-checking platforms verify political statements and viral content circulating on social media while continuously personalizing content in a bid to adapt to market demand and consumers' tastes. Their business model completely differs from legacy media in terms of revenue sources.

Through in-depth interviews, this article expands upon the findings presented in previous literature to gain further insight into the standards, values, and underlying practices embedded in Spanish and Latin American projects while identifying the specific challenges currently facing these organizations. This qualitative study is informed by the perspectives of decision-makers from eight active organizations in seven countries: (Chequeado, UYCheck, Maldita.es, 
Newtral, Fact Checking, Agência Lupa, Ecuador Chequea, and ColombiaCheck).

\section{Method}

The objective of this research was to expand both the theoretical and practical understanding of how factchecking is performed by the following independent platforms across seven different countries in Latin America and Spain: Chequeado (Argentina), UYCheck (Uruguay), Maldita.es and Newtral (Spain), Fact Checking (Chile), Agência Lupa (Brazil), Ecuador Chequea (Ecuador), and ColombiaCheck (Colombia).

The aforementioned independent non-profit organizations are integrated into the Reporters' Lab database at Duke University and were purposively selected due to their trajectory and visibility within their home countries. Seven of the platforms under consideration are members of the LATAM Chequea network (https:// chequeado.com/proyectos/latam-chequea) and, with the exception of UYCheck, are verified signatories of the IFCN code of principles (Table 1). Following the criteria established by Humprecht (2020), Agência Lupa was also considered as a project within the 'NGO model' (Graves \& Cherubini, 2016). The platform is now hosted on the Piauí magazine website but was established and operates as an independent project (Palau-Sampio, 2018). To allow space for a broader range of perspectives within this model, a leading project launched in the higher education environment (Fact Checking, created by the Pontifical Catholic University of Chile) was also incorporated into the sample. Three research questions guided this study:

RQ1: How many people work in these projects? What is their agenda and volume of publication?

RQ2: Which procedures and resources are employed by these organizations? How do they disseminate fact-checks and what role does the audience play in the process?
RQ3: What are the major challenges faced by these platforms and how do editors evaluate the impact of fact-checking to counter disinformation?

Eight in-depth interviews were conducted with the decision-makers representing these platforms: Laura Zommer (Chequeado), Clara Jiménez (Maldita.es), Eliana Álvarez (UYCheck), Enrique Núñez (Fact Checking), Gabriel Narváez (Ecuador Chequea), Pablo Medina (ColombiaCheck), and Natália Leal (Agência Lupa), along with the editorial team of Newtral. The first six interviews, ranging between 60 and 90 minutes in length, were conducted between June and July 2019 via Skype. Conversations were audio recorded for subsequent transcription and analysis. The last two interviews were conducted via email. Questionnaires were sent to Agência Lupa and Newtral during the aforementioned period but were returned to the authors in February 2020. Newtral answered the questionnaire considering the viewpoints of the editorial team as a whole. Therefore, quotes are not attributed to a single editor or decision-maker, as is the case with the rest of interviewees.

Interviews with decision-makers have been employed in recent studies on fact-checking (Graves \& Anderson, 2020; Palomo \& Sedano, 2018; Singer, 2018, 2020). In-depth interviews allow researchers to get a closer perspective towards a part of the object of study that cannot be approached through content analysis, providing them with breadth and depth of nuances and details arising from first-hand descriptions. As a tool for qualitative interviews, Skype allows researchers "to transcend geographical boundaries" (Lo lacono, Symonds, \& Brown, 2016, p. 3), thus enabling them to broaden the range and diversity of initiatives that can be examined. In addition, "with the use of VolP technologies for interviews, time can be used more flexibly, around the needs of participants, while retaining synchronicity with the interviewer" (Lo lacono et al., 2016, p. 5).

The conversational scripts contained a total of 28 questions, which pivoted around the following areas arising from the research questions: (1) description of

Table 1. Characteristics of the fact-checking platforms examined in the study.

\begin{tabular}{|c|c|c|c|c|c|c|}
\hline Project & Website & Country & Creation & Staff & $\begin{array}{l}\text { LATAM } \\
\text { Chequea }\end{array}$ & $\begin{array}{c}\text { IFCN } \\
\text { signatory }\end{array}$ \\
\hline Chequeado & https://chequeado.com & Argentina & 2010 & 30 & Yes & Yes \\
\hline UYCheck & http://uycheck.com & Uruguay & 2014 & $8-9$ & Yes & No \\
\hline Fact Checking & https://factchecking.cl & Chile & 2013 & 8 & No & No \\
\hline Agência Lupa & https://piaui.folha.uol.com.br/lupa & Brazil & 2015 & 10 & Yes & Yes \\
\hline Ecuador Chequea & http://www.ecuadorchequea.com & Ecuador & 2016 & 3 & Yes & Yes \\
\hline ColombiaCheck & https://colombiacheck.com & Colombia & 2016 & 8 & Yes & Yes \\
\hline Maldita.es & https://maldita.es & Spain & 2014 & 15 & Yes & Yes \\
\hline Newtral & https://www.newtral.es & Spain & 2018 & 8 & Yes & Yes \\
\hline
\end{tabular}


projects and personnel; (2) agenda, volume, and frequency of checks; (3) fact-checking procedures and routines employed; (4) dissemination of fact-checks; (5) role of the public; and (6) editors' opinions on the challenges they face and the impact of fact-checking platforms as counteroffensives to disinformation. In order to properly design the interview guides (Kvale \& Brinkmann, 2009, p. 97), we collected information offered by these organizations on their websites. This task aimed to design a solid script that would include key elements regarding the verification process and the resources employed as well as lesser-known aspects that would provide crucial information regarding fact-checking practice, its perceived impact, and the main concerns according to fact-checkers.

The interviews were transcribed and analysed employing the constant comparison technique (Wimmer \& Dominick, 2013). Qualitative data arising from interview transcripts were assigned to the six specific themes of the study, allowing for the comparison and contrast of the material. Interview transcription and coding were assessed by all the authors to ensure the completeness and trustworthiness of data (Janesick, 2015).

\section{Results}

\subsection{Description of Projects and Personnel}

As a pioneering project in the Latin American landscape, Chequeado was founded in 2010 as a reaction to the absence of a space for factual information in mainstream media. The willingness to contribute to democratic wellbeing is a fundamental value shared by all the projects analysed. Some of these initiatives specifically emerged with the aim of monitoring political speech during episodes of great importance, such as the 2014 Uruguayan presidential elections (UY Check), the vote on the peace agreement with the FARC in 2016 (ColombiaCheck), or the 2017 presidential and legislative election campaigns in Ecuador (Ecuador Chequea). In the case of Maldita.es, the proliferation of disinformation following the Catalan independence referendum on October 1, 2017, was decisive in reinvigorating Maldita Hemeroteca, an initiative launched in 2014 by journalists Julio Montes and Clara Jiménez.

Fact-checking organizations in the Latin American and Spanish sphere are inspired by best practice in the US and Europe. The editors agreed that they consider PolitiFact.com as a role model, but also mentioned The Washington Post's Fact Checker and FactCheck.org (US); Channel 4 and FullFact (UK); and Le Monde and Liberation (France). Notably, decision-makers at Colombia Check, Ecuador Chequea, Maldita.es, UYCheck, and Agência Lupa considered Chequeado as a fundamental reference: "they very kindly shared their method with us and gave us the initial training and we have been adapting the method," Gabriel Narváez pointed out.

These organizations maintain close contact with other projects, illustrating the way in which fact-checking is understood as an international community of practice. Six projects are signatories of the IFCN Code of Principles (see Table 1). Interestingly, in 2014, Chequeado promoted the LATAM Chequea network. In their first meeting, journalists from 17 organizations were able to share their experiences and the tools used to verify information. Today, this network consists of 22 participating organizations from 15 countries, including 6 of the initiatives examined. Members of this alliance have recently developed a platform to combat disinformation on Covid-19 (https://www.chequeado.com/latamcoronavirus).

The teams that make up these projects are generally small (see Table 1). As regards to Fact Checking (Chile), the journalism students conducting the verifications, which range between 20 and 55 per group, are supervised by two editors, two lecturers, and four teaching assistants. Most teams rely mainly on journalists. At Maldita.es, all members have undergone training in journalism, while other projects present a more multidisciplinary team. Newtral has journalists with diverse profiles, with training in economics or even in law. UYCheck's team is formed by professionals with backgrounds in political science, sociology, psychology, journalism, economic development, and graphic design. For its part, Chequeado is composed of journalists, economists, engineers, political scientists, and sociologists.

\subsection{Agenda, Volume, and Frequency of Checks}

According to the decision-makers interviewed, the projects examined address a wide range of topics, among which politics, economics, education, science, and health prevail. The particular political context of each country determines the agenda: For example, in Colombia Check, the verifications on the peace agreement have a significant weight in their output while the Catalan independence referendum in 2017 was crucial for the launch of Maldita.es in Spain.

Despite operating with small teams, the capacity of these projects to verify facts is noteworthy (see Table 2). Although the volume of publication can be quite different depending on the platform, most of them complete an average of, at least seven verifications per week, except UYCheck, which publishes two or three per week, and the Spanish platforms (Maldita.es and Newtral), which produce and average of 25 weekly verifications. The shared criteria employed to select content is news relevance: of the person, of the topic, or of the repercussion/virality that the issue may have. The statements from institutional sources have a fundamental weight in the agenda. As Gabriel Narváez emphasizes:

When public representatives work with incorrect figures that do not reveal factual realities, what ends up happening is that the public policies that are built around these discourses are also incorrect... it is essential for us to carry out surveillance work. 
Table 2. Volume of publication.

\begin{tabular}{ll}
\hline Project & Number of fact-checks per week \\
\hline Chequeado & $10-15$ \\
UYCheck & $2-3$ \\
Fact Checking & $60-70$ (per semester) \\
Agência Lupa & $10-15$ \\
Ecuador Chequea & 7 \\
ColombiaCheck & $10-13$ \\
Maldita.es & 25 \\
Newtral & 25 \\
\hline
\end{tabular}

\subsection{Procedures and Resources for Debunking Disinformation}

The fact-checking projects examined employ transparent and robust methodologies to guarantee a consistent verification process. The methodology established by Chequeado is shared by other initiatives, which follow the same workflow with small nuances (Figure 1).

The number of categories used to classify fact-checks ranges between four and nine (see Table 3). According to Gabriel Narváez, having a limited range of categories allows fact-checking platforms "to be specific and not open the scope too much in order to adequately convey the result to users." This framework is adapted to address disinformation on the Internet and social media. Since in many cases it is not possible to contact the original source, online tools and other methodologies such as interviews are used to verify data.

To carry out political fact-checks, all projects consult official and alternative sources: international organizations, civil society organizations, consultants, foundations, experts and researchers, and scientific literature. Depending on the topic or access difficulties, these consultations are made at the same time "as you don't know who will answer you first" (Laura Zommer). Organizations have clearly identified their most widely used sources (see Table 4), with the exception of Newtral and Agência Lupa, which does not have such a list because they use different sources depending on the type of information they are aiming to verify.

Interviewees admitted that their relationships with the sources they check is generally respectful. As Pablo Medina stresses, "some of them do not like it very much, but most political sources are used to it and end up answering us." A good practice shared by these projects is to guarantee the right of reply. According to Laura Zommer, "if they answer us with data and arguments that prove them right, we obviously correct. And if not, we ignore it." Clara Jiménez points out that "nuances have been added to certain fact-checks from talking to the politician."

In most initiatives, it is common for one person to carry out each verification, with the exception of more complex issues. Before publishing, verifications go through various control filters (Table 5), ensuring the rigour and trustworthiness of the process. As a general rule, these projects do not establish a maximum time for verification: some fact-checks appear even three months after claims have been made. Although some topics may begin to be researched but eventually not be finalized,

\section{Selecting a claim from the public sphere and weighing its relevance}

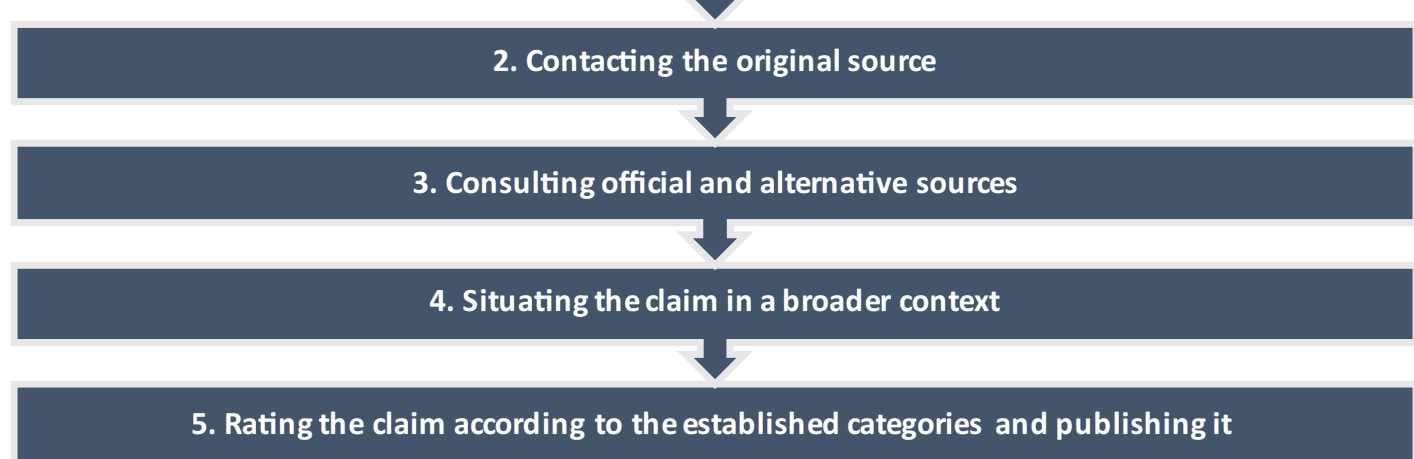

Figure 1. Fact-checking workflow. Source: Authors' elaboration with information from Chequeado's website (Chequeado, 2020) and interviewees' responses. 
Table 3. Categories employed by fact-checking platforms.

\begin{tabular}{|c|c|c|}
\hline Project & Categories & Definition of categories \\
\hline Chequeado & 9 & $\begin{array}{l}\text { Inchequeable (unverifiable), verdadero* (true), verdadero...pero (true...but), } \\
\text { discutible (disputable), apresurado (hasty), exagerado (exaggerated), } \\
\text { engañoso (deceptive), insostenible (untenable), falso* (false). }\end{array}$ \\
\hline UYCheck & 7 & $\begin{array}{l}\text { Verdadero* (true), verdad a medias (half true), inflado (inflated), ni ni (neither nor), } \\
\text { engañoso (deceptive), falso* (false), ridículo (ridiculous). }\end{array}$ \\
\hline Fact Checking & 6 & $\begin{array}{l}\text { Creíble* (credible), creíble pero* (credible, but), sería creíble pero (would be credible, } \\
\text { but), se puso creativ@ (creative), no es creíble (not credible), } \\
\text { ciencia ficción (science fiction). }\end{array}$ \\
\hline Agência Lupa & 9 & $\begin{array}{l}\text { Verdadeiro (true), verdadeiro mas (true, but), ainda é cedo para dizer (early to say), } \\
\text { exagerado* (exaggerated), contraditório (contradictory), subestimado (understated), } \\
\text { insustentável (untenable), falso* (false), de olho ("we are watching"). }\end{array}$ \\
\hline Ecuador Chequea & 4 & Cierto (true), sí pero* (yes, but), insostenible (untenable), falso* (false) \\
\hline ColombiaCheck & 5 & $\begin{array}{l}\text { Verdadero (true), verdadero pero (true, but), cuestionable* (questionable), } \\
\text { falso* (false), inchequeable (unverifiable). }\end{array}$ \\
\hline Maldita.es & 6 & $\begin{array}{l}\text { Political fact-checking: Falso* (false), verdadero pero (true, but), falso pero (false, but); } \\
\text { Disinformation: Bulo (hoax), qué sabemos (what we know) y no hay pruebas (no proof). }\end{array}$ \\
\hline Newtral & 4 & Verdadero (true), verdad a medias (half true), engañoso* (deceptive), falso* (false). \\
\hline
\end{tabular}

Note: The most-used categories by each fact-checking platform are marked with an asterisk.

there is widespread awareness among editors that "it is very possible that they will return to the agenda" (Laura Zommer).

Regarding technological resources, fact-checking projects make intensive use of open-access digital tools: search engines (reverse image search in Google, Yandex, and Tineye), tools aimed at verifying videos and photos (InVID, FotoForensics) and map verification applications (Google Maps, Wikimapia, OpenStreetMaps,
Yandex Maps, Baidu Maps, Naver Maps). Other platforms such as Chequeado, Agência Lupa, and Colombia Check use CrowdTangle, a Facebook verification tool that helps monitor the virality of fake content on social networks. This 'arsenal' of possibilities is completed, in the case of Chequeado, with 'Chequeador,' an inhouse bot that "reads 30 Argentinian newspapers every day, the speeches of the president, and everything that happens in the congress" (Laura Zommer). In all cases,

Table 4. Most-employed sources.

\begin{tabular}{|c|c|}
\hline Project & Most-employed sources \\
\hline Chequeado & $\begin{array}{l}\text { National Institute of Statistics and Censuses (INDEC); Ministry of Labour; CIPPEC (independent } \\
\text { nonprofit organization on public policies); Ministry of Economy; National Social Security } \\
\text { Administration (ANSES). }\end{array}$ \\
\hline UYCheck & $\begin{array}{l}\text { National Institute of Statistics (INE); Ministry of the Interior; Central Bank of Uruguay; } \\
\text { The World Bank; Ministry of Social Development. }\end{array}$ \\
\hline Fact Checking & Governments' and sub-secretaries' websites; National Congress of Chile website; Transparency portal. \\
\hline Agência Lupa & Varies according to the type of information that is being checked. \\
\hline Ecuador Chequea & $\begin{array}{l}\text { Central Bank of Ecuador; National Institute of Statistics and Censuses (INEC); Ministries' websites; } \\
\text { Twitter accounts from the National Assembly and the Constitutional Court of Ecuador; Transparency } \\
\text { websites created by the government. }\end{array}$ \\
\hline ColombiaCheck & $\begin{array}{l}\text { National Civil Registry; Misión de Observación Electoral (NGO); National Department of } \\
\text { Statistics (DANE); Ministry of the Interior; Office of the Attorney General of Colombia; } \\
\text { KROC Institute for International Peace Studies. }\end{array}$ \\
\hline Maldita.es & National Institute of Statistics (INE); Eurostat; Ministry of Labour. \\
\hline Newtral & Varies according to the type of information that is being checked. \\
\hline
\end{tabular}


Table 5. Number and description of filters employed by fact-checking platforms.

\begin{tabular}{lcl}
\hline Project & Filters & Description of filters \\
\hline Chequeado & 4 & Reporter, additional journalist, two editors \\
UYCheck & 3 & Reporter, two editors \\
Fact Checking & 3 & Reporter, two editors \\
Agência Lupa & 2 & Reporter, editor \\
Ecuador Chequea & 3 & Reporter, additional journalist, editor \\
ColombiaCheck & 2 & Reporter, editor \\
Maldita.es & 4 & Reporter, three editors \\
Newtral & 4 & Reporter, additional journalist, two editors \\
\hline
\end{tabular}

the fact-checkers themselves employ these tools, as no special training or background in computer science is required to use them.

\subsection{Dissemination of Fact-Checks}

To ensure the broadest dissemination possible, factchecks are published both on the projects' websites and social media accounts. Some verifications also appear in other outlets, such as Eldiario.es, which has a section for Maldita.es, or the Teletrece programme, which welcomes verifications conducted by Fact Checking. For its part, UYCheck collaborates with the VTV programme "En la Mira" and has also worked with other Uruguayan newspapers such as El País. These experiences demonstrate the mainstream media's growing interest in factchecking, a task that many outlets cannot assume due to their structures, professional routines, or political ties. As Eliana Álvarez explains:

Media find it interesting and they wish they could do this job, but many times they cannot do it. They show us confidence in our work: We can be wrong in the data, but nobody distrusts that we are playing the political game on anyone.

Independence is not always well-received, as evidenced by the case of Ecuador Chequea. The project has agreements with two radio stations and with the Criterios magazine of the Quito Chamber of Commerce. However, its critical distance from power has limited its opportunities in other spaces, as Gabriel Narváez explains:

Between November 2018 and January 2019, we had an agreement with the Ecuadorian public media and our fact-checks were published in the newspaper El Telégrafo-one of the newspapers with the largest circulation nationwide-Radio Pública FM, and Ecuador TV. We are trying to renew that contract, I believe it generated impact...however, not everyone agrees that the media should openly say that the president is a liar.

\subsection{Role of the Public}

Audiences' participation is essential to these projects. Myriad opportunities are offered to foster close relationships with citizens, including email, postal mail, forms on websites, and social media (WhatsApp, Twitter, Facebook, and Instagram). Through these channels, audiences send comments and materials and suggest verifications. They also provide criticism or corrections to published fact-checks. Clara Jiménez highlights that new channels facilitate citizens' involvement in the fight against disinformation: "We have solved a lot of things using our own community. If citizens get involved in the fight against lies, they contribute to the viralization of truth."

According to the interviewees, fact-checks proposed by audiences play a crucial role in these projects: two to three weekly checks at Chequeado are proposed by the public. In Agência Lupa, approximately $10 \%$ of the monthly production starts from public suggestions, while in Ecuador Chequea these topics represent between $20-30 \%$ of its production. For its part, Newtral developed a Verification on Demand application for WhatsApp, where the team replied to 6,100 messages between July 2018 and the end of 2019. In some cases, such as in Colombia Check, limited structures complicate participation management, as Pablo Medina explains:

We have a WhatsApp number and Twitter and Facebook accounts and we check them periodically. At the moment we do not make much publicity of these channels because we do not have someone who can constantly review and organize all the requests that come to us.

\subsection{Editors' Opinions on the Challenges and the Impact of Fact-Checking Platforms}

These organizations acknowledge they face several problems and challenges. The first challenge shared across projects refers to accessing information. As Laura Zommer mentions: 
Sometimes there is no updated data for all phenomena, or sometimes data is not public. We only work with data that we can see or contrast, not with what somebody tells us. Our contract with audiences does not necessarily imply that citizens should believe us, they should be able to check data by themselves.

The second core challenge faced by fact-checking projects refers to the scarcity of resources. As Natália Leal points out, "there is a financial problem common to all journalistic initiatives and for companies like ours, it is something that weighs heavily." Most teams are made up of part-time employees or volunteers, which limits the volume and range of issues that can be addressed. A third crucial challenge, in the eyes of Enrique Núñez, is delivering fact-checking to mass audiences:

Fact-checking is an elite product. I am especially concerned about this in Latin American countries, which are countries of oral culture, of late literacy, and where television is still the most consumed medium. To be massive in these countries, fact-checking must think about that oral culture. Fact-checking must be on television and radio programmes.

Going forward, interviewees defended the crucial role of fact-checking as a counter-offensive to disinformation and as a tool that "helps to create a civic spirit on how information should be consumed" (Eliana Álvarez). Despite the aforementioned difficulties, the interviewees were optimistic about the future of fact-checking. As Pablo Medina highlights:

There are going to be fewer mainstream media and more small media. Fact-checking platforms are going to be part of that universe as a very particular way of doing journalism. Fact-checking is what journalism should be doing but has stopped doing for many reasons: because of the desire to get clicks and because there is not enough budget to hire people to verify content.

\section{Discussion and Conclusion}

In a time characterized by profound challenges, factchecking interventions represent an alternative destination in journalism that seeks to combat the spread of disinformation, educate citizens, and contribute to restoring the credibility of journalism. This article aims to contribute to the existing literature on fact-checking by paying attention to key aspects regarding this phenomenon through the analysis of eight verification initiatives in Latin America and Spain.

The research builds on previous works focused in those territories (Bernal-Triviño \& Clares-Gavilán, 2019; Chaves \& Braga, 2019; López-Pan \& RodríguezRodríguez, 2020; Magallón-Rosa, 2019; Palau-Sampio, 2018; Palomo \& Sedano, 2018; Rodríguez-Pérez, 2020;
Ufarte-Ruiz et al., 2020; Vizoso \& López-García, 2019; Vizoso \& Vázquez-Herrero, 2019) by offering a deep understanding of the standards, values, and practices while identifying the specific challenges that eight independent organizations in Argentina, Brazil, Chile, Colombia, Ecuador, Spain, and Uruguay currently face. Through qualitative interviews, this work contributes to the fact-checking literature by offering decision-makers' insight on the volume and frequency of checks, procedures, and the perceived role of the public. This contribution also sheds light on fact-checkers' opinions on the impact of their work and the difficulties they have to overcome. The novelty of this work is that it combines the study of several fact-checking projects in two regions which, despite their differences, have shown remarkable similarities in terms of their media landscapes and ongoing journalistic challenges.

Findings indicate that the outlets examined in Latin American and Spanish contexts carry out an intensive task. The projects analysed were founded as a reaction to the absence of space for factual information in the mainstream media and with the aim of monitoring political speech during important political episodes (such as presidential elections, a peace process, or a referendum) when disinformation is more likely to arise, circulate, and potentially harm democratic decision-making.

Indeed, despite relying on small teams, their capacity to verify facts is noteworthy: Most of the Latin American sites examined offer a minimum of seven fact-checks per week while the Spanish ones complete up to 25 weekly verifications. In addition to this, the majority of the interviewees assure that they do not establish a maximum time for verification. This implies that, even when the latest news prevails, fact-checking differs from mainstream journalism practice since it breaks the traditional concept of urgency associated with news reporting (Zelizer, 2018).

All platforms shared fixed criteria regarding content selection: news relevance due to the person, the topic or the repercussion, and/or virality on mainstream and social media. Decision-makers point out that they address different topics in which the analysis of public representatives' claims has a fundamental weight in the agenda. Inspired by best practice in the US and Europe and the model established by Chequeado, all sites considered employ innovative, robust, and transparent methodologies that guarantee a consistent verification process. These organizations consult a broad range of official and alternative sources to check data while leveraging the power of digital tools. Notably, audience participation is considered critical to help locate and count disinformation circulating through myriad platforms.

Overall, the fact-checking platforms examined fulfil a function that many organizations in Latin America and Spain have halted due to constrained resources, hyperaccelerated cycles, and the impact of commodification on news production and distribution (Usher, 2018). They occupy a distinctive domain within journalism 
by reclaiming the importance of accuracy, independence, rigour, contextualization, completeness, and transparency, identified as normative values of journalism (Christians et al., 2009). Professional values highlighted by the interviewees are consistent with those identified as essential by other fact-checkers across different continents (Singer, 2020). With their approach, they also seek to transcend some of the specific limitations and constraints shared across the Spanish and Latin American media systems, such as limited journalistic autonomy, high levels of polarization, and the politicization of the media (Baumgartner \& Bonafont, 2015; Freedom House, 2020; Hallin \& Papathanassopoulos, 2002; Luengo et al., 2017; Masip et al., 2018; Mauri-Rios et al., 2020; Saldaña \& Mourão, 2018).

Interviewees identified three core challenges in fact-checking practice: difficulties in accessing public data, limited resources, and the need to reach wider audiences. These major concerns are widely shared across different journalistic cultures (Amazeen, 2020; Humprecht, 2020; Lowrey, 2017; Singer, 2020). There are different ways in which the outlets analysed try to respond to these challenges. First, they expose the lack of transparency or problems in accessing public data in the territories they operate (Saldaña \& Mourão, 2018) by doing the exact opposite: offering data to readers in the most transparent way. Secondly, they overcome the lack of resources by creating multidisciplinary and highly qualified teams while sharing knowledge between platforms. Finally, they constantly work to broaden their audience through social media and by establishing collaborations with mainstream outlets.

Looking forward, fact-checking operations could be strengthened and expanded by fostering cooperation. The fact-checking movement is making steady progress thanks to initiatives such as the IFCN and LATAM Chequea networks. Further collaboration between organizations can help fact-checkers research more complex topics. Capitalizing on journalists' increasing interest in participating in national and transnational collaborative projects (Cueva-Chacón \& Saldaña, 2020), fact-checkers can materialize partnerships that help to reduce production costs, share content across platforms and facilitate the dissemination of verifications in different countries. Enhancing a continuous dialogue between fact-checking and mainstream media organizations is of utmost importance. The experiences developed by sites such as Agência Lupa or Newtral reveal that agreements with news outlets help give broader visibility to fact-checkers' output while providing them with additional income. Partnerships with universities represent a supplementary source of revenue. Initiatives such as verification courses offered by Newtral and Maldita.es indicate that there is a growing need for alliances between newsrooms and academia. Fact-checking organizations can help universities by assisting them in designing and introducing verification modules to curricula, thus contributing to strengthening future journalists' verification skills.
Moreover, fact-checking institutions can contribute to society at large by encouraging media literacy activities. The organization of meetings, workshops, and training sessions can promote critical thinking among citizens so that they can make informed decisions about the content they consume. According to Ana Pastor, founder of Newtral, "citizens should be able to fact-check by themselves and also to fact-check us" (Tardáguila, 2019).

The results of this qualitative study should be seen in light of its limitations. The findings cannot be generalized to all organizations from the independent/NGO model. Yet, information from seven different countries helps to advance true understandings of fact-checking practice in Latin America and Spain. To broaden the scope of this analysis, future research should monitor the evolution of fact-checking interventions in the Latin American and Spanish contexts while trying to understand the practices used by other outlets. The incipient collaboration between fact-checking platforms and major companies such as Google and Facebook (Graves \& Anderson, 2020) should also be closely followed. Those actors can contribute to funding fact-checking platforms, assist them in the development of tools for automated fact-checking and help them reach broader audiences. Fact-checking platforms can also leverage their expertise to verify the accuracy of content on those platforms. Recent developments in this field include the participation of Chequeado, Newtral and Maldita.es in Facebook's data verification programme. In addition, future studies should investigate how fact-checkers operate under particularly challenging contexts, such as during the Covid-19 crisis.

Another avenue for future research revolves around gender. In contrast to other areas in journalism, gender does not seem to be a setback in fact-checking practice. In fact, many platforms at the international level are driven by women. While this field "can serve as an example for other areas" (Eliana Álvarez), the extent to which women's entrepreneurship in fact-checking is a response to the structural gender divide that permeates the sector should be interrogated.

Finally, the involvement of audiences also lends opportunities for future examination. Focus groups and interviews would allow a much more nuanced understanding of citizens' experiences and expectations with fact-checking platforms. Audiences' perspectives will also allow researchers to identify additional ways in which those sites could be improved to continue contributing to democratic wellbeing.

\section{Acknowledgments}

Thanks are extended to the anonymous reviewers and the academic editors for their constructive comments and suggestions. This study is part of the research project "Media Accountability Instruments against Disinformation: The Impact of Fact-Checking Platforms as Media Accountability Tools and Curricular Proposal," funded 
by the Spanish Ministry of Science and Innovation and the State Research Agency (FACCTMedia, PID2019106367GB-I00/AEI/10.13039/501100011033).

\section{Conflict of Interests}

The authors declare no conflict of interests.

\section{References}

Allcott, H., \& Gentzkow, M. (2017). Social media and fake news in the 2016 election. Journal of Economic Perspectives, 31(2), 211-236. https://doi.org/10.1257/ jep.31.2.211

Amazeen, M. A. (2020). Journalistic interventions: The structural factors affecting the global emergence of fact-checking. Journalism, 21(1), 95-111. https://doi. org/10.1177/1464884917730217

Baumgartner, F. R., \& Bonafont, L. C. (2015). All news is bad news: Newspaper coverage of political parties in Spain. Political Communication, 32(2), 268-291. https://doi.org/10.1080/10584609.2014.919974

Bernal-Triviño, A., \& Clares-Gavilán, J. (2019). Uso del móvil y las redes sociales como canales de verificación de fake news: El caso de Maldita.es [Using mobile devices and social networks as checking channels of fake news: The case of Maldita.es]. El Profesional de La Información, 28(3), 1-8. https://doi.org/ 10.3145/epi.2019.may.12

Brandtzaeg, P. B., Følstad, A., \& Chaparro Domínguez, M. Á. (2018). How journalists and social media users perceive online fact-checking and verification services. Journalism Practice, 12(9), 1109-1129. https://doi. org/10.1080/17512786.2017.1363657

Chaves, M., \& Braga, A. (2019). The agenda of disinformation: "Fake news" and membership categorization analysis in the 2018 Brazilian presidential elections. Brazilian Journalism Research, 15(3), 474-495. https://doi.org/10.25200/BJR.v15n3.2019.1187

Chequeado. (2020). Método [Method]. Chequeado. Retrieved from https://chequeado.com/metodo

Cheruiyot, D., \& Ferrer-Conill, R. (2018). "Fact-checking Africa": Epistemologies, data and the expansion of journalistic discourse. Digital Journalism, 6(8), 964-975. https://doi.org/10.1080/21670811.2018. 1493940

Christians, C. G., Glasser, T. L., McQuail, D., Nordenstreng, K., \& White, R. A. (2009). Normative theories of the media: Journalism in democratic societies. Urbana, IL: University of Illinois Press.

Cueva-Chacón, L. M., \& Saldaña, M. (2020). Stronger and safer together: Motivations for and challenges of (trans)national collaboration in investigative reporting in Latin America. Digital Journalism. Advance online publication. https://doi.org/10.1080/ 21670811.2020.1775103

Farrer, G. (2017). Fact check unit an opportunity for a new kind of J. education. Asia Pacific Media
Educator, 27(1), 10-16. https://doi.org/10.1177/ $1326365 \times 17702269$

Freedom House. (2020). Freedom in the world 2020: A leaderless struggle for democracy. Washington, DC: Freedom House. Retrieved from https:// freedomhouse.org/report/freedom-world/2020/ leaderless-struggle-democracy

García-Marín, D. (2020). Infodemia global: Desórdenes informativos, narrativas fake y fact-checking en la crisis de la Covid-19 [Global infodemic: Information disorders, false narratives, and fact checking during the Covid-19 crisis]. El Profesional de la Información, 29(4), e290411. https://doi.org/10.3145/epi. 2020.jul.11

Graves, L. (2016). Deciding what's true: The rise of political fact-checking in American journalism. New York, NY: Columbia University Press.

Graves, L. (2018). Boundaries not drawn: Mapping the institutional roots of the global fact-checking movement. Journalism Studies, 19(5), 613-631. https:// doi.org/10.1080/1461670X.2016.1196602

Graves, L., \& Anderson, C. W. (2020). Discipline and promote: Building infrastructure and managing algorithms in a "structured journalism" project by professional fact-checking groups. New Media and Society, 22(2), 342-360. https://doi.org/10.1177/ 1461444819856916

Graves, L., \& Cherubini, F. (2016). The rise of factchecking sites in Europe. Oxford: Reuters Institute for the Study of Journalism. Retrieved from https:// reutersinstitute.politics.ox.ac.uk/sites/default/files/ research/files/The\%2520Rise\%2520of\%2520FactChecking\%2520Sites\%2520in\%2520Europe.pdf

Haigh, M., Haigh, T., \& Kozak, N. I. (2018). Stopping fake news: The work practices of peer-to-peer counter propaganda. Journalism Studies, 19(14), 2062-2087. https://doi.org/10.1080/1461670X.2017.1316681

Hallin, D., \& Papathanassopoulos, S. (2002). Political clientelism and the media: Southern Europe and Latin America in comparative perspective. Media, Culture and Society, 24(2), 175-195. https://doi.org/ 10.1177/016344370202400202

Hameleers, M., \& van der Meer, T. G. L. A. (2020). Misinformation and polarization in a high-choice media environment: How effective are political factcheckers? Communication Research, 47(2), 227-250. https://doi.org/10.1177/0093650218819671

Humprecht, E. (2019). Where "fake news" flourishes: A comparison across four Western democracies. Information Communication and Society, 22(13), 1973-1988. https://doi.org/10.1080/1369118X. 2018.1474241

Humprecht, E. (2020). How do they debunk "fake news"? A cross-national comparison of transparency in fact checks. Digital Journalism, 8(3), 310-327. https://doi. org/10.1080/21670811.2019.1691031

Janesick, V. J. (2015). Peer debriefing. In G. Ritzer (Ed.), The Blackwell encyclopedia of sociology). Lon- 
don: John Wiley \& Sons. https://doi.org/10.1002/ 9781405165518.wbeosp014.pub2

Kvale, S., \& Brinkmann, S. (2009). Interviews: Learning the craft of qualitative research interviewing. Thousand Oaks, CA: Sage.

Lo lacono, V., Symonds, P., \& Brown, D. H. K. (2016). Skype as a tool for qualitative research interviews. Sociological Research Online, 21(2), 103-117. https://doi.org/10.5153/sro.3952

López-Pan, F., \& Rodríguez-Rodríguez, J. (2020). El fact checking en España: Plataformas, prácticas y rasgos distintivos [Fact checking in Spain: Journalistic projects, practices and distinctive features]. Estudios sobre el Mensaje Periodístico, 26(3), 1045-1065. https://doi.org/10.5209/esmp.65246

Lowrey, W. (2017). The emergence and development of news fact-checking sites: Institutional logics and population ecology. Journalism Studies, 18(3), 376-394. https://doi.org/10.1080/1461670X.2015.1052537

Luengo, M., Maciá-Barber, C., \& Requejo-Alemán, J. L. (2017). Evaluating organisational ethics in Spanish news media. Journalism, 18(9), 1142-1162. https:// doi.org/10.1177/1464884916643682

Magallón-Rosa, R. (2019). Verificado México 2018: Desinformación y fact-checking en campaña electoral [Verificado Mexico 2018: Disinformation and factchecking on electoral campaign]. Revista de Comunicación, 18(1), 234-258. https://doi.org/10.26441/ RC18.1-2019-A12

Masip, P., Ruiz, C., \& Suau, J. (2018). Monitoring media pluralism in Europe: Application of the Media Pluralism Monitor 2017 in the European Union, FYROM, Serbia \& Turkey. Country Report: Spain. Florence: Centre for Media Pluralism and Media Freedom. Retrieved from https://cmpf.eui.eu/wp-content/ uploads/2018/11/Spain_MPM2017_countryreport.pdf

Mauri-Rios, M., López-Meri, A., \& Perales-García, C. (2020). The professional ethics of journalists in the face of governments and politicians: Perceptions of professionals and citizens in Spain. Revista Latina de Comunicación Social, 77, 295-308. https://doi.org/ 10.4185/RLCS-2020-1459

McCluskey, M., \& Kim, Y. M. (2012). Moderatism or polarization? Representation of advocacy groups' ideology in newspapers. Journalism \& Mass Communication Quarterly, 89(4), 565-584. https://doi.org/10.1177/ 1077699012455385

Molina, M. D., Sundar, S. S., Le, T., \& Lee, D. (2019). “Fake news" is not simply false information: A concept explication and taxonomy of online content. American Behavioral Scientist. Advance online publication. https://doi.org/10.1177/0002764219878224

Newman, N. (2020). Executive summary and key findings of the 2019 report. Oxford: Reuters Institute for the Study of Journalism. Retrieved from http://www.digitalnewsreport.org/survey/2019/ overview-key-findings-2019/
Palau-Sampio, D. (2018). Fact-checking and scrutiny of power: Supervision of public discourses in new media platforms from Latin America. Communication and Society, 31(3), 347-365. https://doi.org/10.15581/ 003.31.3.347-365

Palomo, B., \& Sedano, J. (2018). WhatsApp como herramienta de verificación de fake news: El caso de $B$ de Bulo [WhatsApp as a verification tool for fake news: The case of B de Bulo]. Revista Latina de Comunicación Social, 2018(73), 1384-1397. https://doi.org/ 10.4185/RLCS-2018-1312

Ramon, X., \& Tulloch, C. (2019). Life beyond clickbait journalism: A transnational study of the independent football magazine market. Communication \& Sport. Advance online publication. https://doi.org/ $10.1177 / 2167479519878674$

Reporters Without Borders. (2020). World press freedom index 2020. Paris: Reporters Without Borders. Retrieved from https://rsf.org/en/ranking

Richardson, N. (2017). Fake news and journalism education. Asia Pacific Media Educator, 27(1), 1-9. https:// doi.org/10.1177/1326365X17702268

Rodríguez-Pérez, C. (2020). Una reflexión sobre la epistemología del fact-checking journalism: retos y dilemas [A reflection on the epistemology of fact-checking journalism: challenges and dilemmas]. Revista de Comunicación, 19(1), 243-258. https://doi.org/ 10.26441/rc19.1-2020-a14

Saldaña, M., \& Mourão, R. R. (2018). Reporting in Latin America: Issues and perspectives on investigative journalism in the region. The International Journal of Press/Politics, 23(3), 299-323. https://doi.org/10.1177/1940161218782397

Singer, J. B. (2018). Fact-checkers as entrepreneurs: Scalability and sustainability for a new form of watchdog journalism. Journalism Practice, 12(8), 1070-1080. https://doi.org/10.1080/17512786.2018.1493946

Singer, J. B. (2020). Border patrol: The rise and role of fact-checkers and their challenge to journalists' normative boundaries. Journalism. Advance online publication. https://doi.org/10.1177/1464884920933137

Stencel, M., \& Luther, J. (2020). Annual census finds nearly 300 fact-checking projects around the world. Duke Reporters' Lab. Retrieved from https:// reporterslab.org/annual-census-finds-nearly-300fact-checking-projects-around-the-world

Tardáguila, C. (2019). Ana Pastor, in Spain: 'Citizens should be able to fact-check by themselves and also to fact-check us.' Poynter.org. Retrieved from https://www.poynter.org/fact-checking/2019/anapastor-in-spain-citizens-should-be-able-to-factcheck-by-themselves-and-also-to-fact-check-us

Ufarte-Ruiz, M. J., Anzera, G., \& Murcia-Verdú, F. J. (2020). Plataformas independientes de fact-checking en España e Italia: Características, organización y método [Independent fact-checking platforms in Spain and Italy: Features, organisation and method]. Revista Mediterránea de Comunicación, 11(2), 23-39. 
https://doi.org/10.14198/MEDCOM2020.11.2.3

UNESCO. (2018). Journalism, fake news \& disinformation: Handbook for journalism education and training. Paris: UNESCO. Retrieved from https://unesdoc. unesco.org/ark:/48223/pf0000265552

Usher, N. (2018). Breaking news production processes in US metropolitan newspapers: Immediacy and journalistic authority. Journalism, 19(1), 21-36. https:// doi.org/10.1177/1464884916689151

Vázquez-Herrero, J., Vizoso, Á., \& López-García, X. (2019). Innovación tecnológica y comunicativa para combatir la desinformación: 135 Experiencias para un cambio de rumbo [Technological and communicative innovation to fight misinformation: 135 Experiences for a change of direction]. El Profesional de La Información, 28(3), e280301. https://doi.org/ 10.3145/epi.2019.may.01

Vizoso, Á., \& López-García, X. (2019). Newtral y Com- probado: Experiencias de fact-checking durante la campaña electoral de las Elecciones Generales en España [Newtral and Comprobado: Fact-checking experiences during the electoral campaign of the Spanish General Elections]. Cuadernos Artesanos de Comunicación, 171, 77-98. https://doi.org/10.4185/ cac171

Vizoso, Á., \& Vázquez-Herrero, J. (2019). Factchecking platforms in Spanish: Features, organisation and method. Communication and Society, 32(1), 127-142. https://doi.org/10.15581/003.32.1. 127-142

Wimmer, R. D., \& Dominick, J. R. (2013). Mass media research: An introduction. Belmont, CA: Cengage Learning.

Zelizer, B. (2018). Epilogue: Timing the study of news temporality. Journalism, 19(1), 111-121. https://doi.org/ $10.1177 / 1464884916688964$

\section{About the Authors}
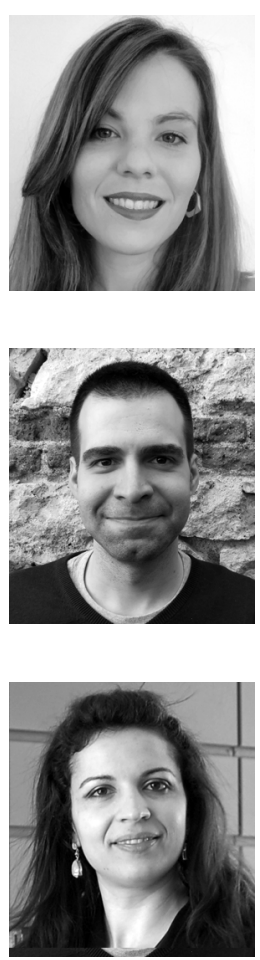

Victoria Moreno-Gil (PhD) is a Lecturer at the School of Communication and Arts of Nebrija University. She holds a PhD in Communication from the Carlos III University and a MA degree in Ethics and Law in journalism from the UNED. She has been a Visiting Researcher at Pompeu Fabra University. Her research focuses on journalism ethics, media accountability, and media literacy. She combines a research career with professional journalism. She currently works for the European Pressphoto Agency (EPA).

Xavier Ramon (PhD) is a Lecturer at the Department of Communication of Pompeu Fabra University. Member of Journalism Research Group (GRP). His research and teaching focus on journalism ethics, media accountability, and sports communication. He has been a Visiting Researcher at the University of Stirling and the University of Glasgow (UK), the University of Alabama (US), and the IOC Olympic Studies Centre (Switzerland). He has participated in three competitive projects on media accountability and fact-checking.

Ruth Rodríguez-Martínez (PhD) is a Lecturer at the Department of Communication at Pompeu Fabra University. A member of the Journalism Research Group (GRP), her research focuses on media ethics, fact-checking, and cultural journalism. She is one of the principal investigators of the funded projects MediaACES and FACCTMedia. She has carried out postdoctoral stays at the Missouri University School of Journalism and the Columbia University in New York (US) and the Laboratoire du Comunicacion et Politique at CNRS (France). 